Article

\title{
The Assessment of Real Estate Initiatives to Be Included in the Socially-Responsible Funds ${ }^{\dagger}$
}

\author{
Fabrizio Battisti *, Maria Rosaria Guarini and Anthea Chiovitti \\ Department of Architecture and Design, Sapienza University of Rome, Via Flaminia, 359, 00196 Rome, Italy; \\ mariarosaria.guarini@uniroma1.it (M.R.G); anthea.chiovitti@uniroma1.it (A.C.) \\ * Correspondence: fabrizio.battisti@uniroma1.it; Tel.: +39-338-107-9177 \\ + This article represents an extension and an in-depth study with a new case study of a paper (for which a \\ publication has been planned) presented at SIEV (Società Italiana di Estimo e Valutazione) seminary \\ “L'influenza sui percorsi valutativi dell'Enciclica Laudato sì" (Rome, 14 and 15 April 2016).
}

Academic Editors: Gwo-Hshiung Tzeng and Kao-Yi Shen

Received: 30 March 2017; Accepted: 30 May 2017; Published: 7 June 2017

\begin{abstract}
The acknowledgment of the ongoing economic and financial crisis involving real estate, creates the need to formulate proposals and scenarios (in real estate) with the characteristics of socially responsible investments. These kind of investments aim towards "sustainable" development both environmentally (safeguarding the shortage of resources such as land, energy, and natural elements), and socially (protecting the population and raising its level of well-being) according to so-called "ethical finance", instead of a mere "speculative" investment. Effectively, real estate is still an investment sector only marginally explored by the socially-responsible funds. Based on these premises, this paper will: (i) briefly analyze the nature of socially-responsible investments, setting their characteristics apart from "traditional investments"; and (ii) propose a possible procedure (of the multi-criteria type) which aims to assess socially-responsible investments in real estate. This will be applied to a case study regarding a social housing initiative in the municipality of Anguillara Sabazia (Rome, Italy).
\end{abstract}

Keywords: socially-responsible investment; multi-criteria decision analysis; real estate; TOPSIS; ethical finance; assessment

\section{Introduction and Aims of the Work}

The "financialization" of the real estate market (Real Estate, hereafter RE) which has increased dramatically since the early 1990s, has gradually brought together very large amounts of capital, according to a clear "speculative" ratio [1]. In this context, the overvaluation of the RE assets put up as collateral for loans (the "subprime crisis") has been all too frequent; this overvaluation generated the "housing bubble" in 2007 from which the still ongoing (2017) widespread economic and financial crisis originated. The opportunity to restore financial levers through Loan To Value (LTV) ratios up to $100 \%$ (of overestimated values) triggered a proliferation of RE initiatives not always born well by the market. On the one hand, these initiatives caused fruitless land consumption; on the other hand, they also had a negative impact on the credit system, damaging all types of investor (institutional, qualified, ordinary). According to some analysts [2] these effects were related to: (i) the belief in a continuous and endless economic growth; (ii) specific responsibilities related to deficient checks during the granting of loans; and (iii) some relevant aspects for the formulation of assessment judgments not having been taken into account, such as: collateral utilities in the long term, the viability of those in debt and environmental and social sustainability.

Focusing on the structural causes which have caused the malfunction of the global economy, and the inability of growth models to simultaneously guarantee social, economic and environmental 
sustainability. The definition of new objectives aiming towards the common good and integral and sustainable development appears to be necessary.

As a consequence of the economic spread, new attention has been given to investment prospects integrating the principles of conventional finance with those of an ethical nature [2]. The first investments related to so-called "ethical finance" date back to the 1920s in the United States. Between the 1970s and 1980s, the concept of ethical finance became widely recognized. In 1976, the Organization for Economic Cooperation and Development (OECD) published guidelines regarding corporate social responsibility. The spread of ethical investment had been moderately growing until the early 2000s, and then increased very rapidly as a result of the persistence of the current global financial crisis [3].

In this context new interest should be devoted to ethical investments and, more specifically, to Corporate Social Responsibility (CSR) or socially-responsible investments whose aim is not to exclusively satisfy the creation of wealth for the investor/shareholder, but rather to produce benefits for the various categories of stakeholders as well. According to Eurosif [4] the designation of socially-responsible investments changed into "sustainable and responsible investment (SRI/s)" which is a long-term investment approach, integrating Environmental, Social, and Governance (ESG) factors during research, analysis and in the selection process of securities within an investment portfolio. SRI/s combine fundamental analysis and "engagement" with an evaluation of ESG factors in order to better capture long term returns for investors, and to benefit society by influencing the behavior of companies [4]. In brief, SRIs are geared towards practical "ethics" in which: (i) the investor's profit, in any case admitted, is fair; (ii) the economic and financial equilibrium is guaranteed over the medium/long term; (iii) the governance aims to reduce corporate and social risks; and (iv) the environmental sustainability is ensured [2].

In the regulatory frameworks of the European states where SRIs are widespread (Germany, France, Spain, England, Italy), there is no regulation aimed to outline the perimeter of action and the specific characteristics of SRI. In general, SRIs are based on a set of practices "voluntarily" adopted and increasingly demanded on a global level by both civil society and the financial world [5]. This may cover different policy areas: (i) environmental: climate change contrast, water optimization, natural resources safeguards, renewable energies development, "agritech" improvements, waste reuse [6,7]; (ii) social: human rights protection, human capital development, "smartech" and "edutech" increase, attraction of talent, social housing, equal opportunities, health and safety, relationships with the community, philanthropy [8-10]; and (iii) governance: independence and remuneration of investors, compliance, corruption contrast, shareholders' rights protection, and risk management [11,12]. The SRIs market is continuously growing: it had a worldwide value of around $\$ 22,000$ billion in 2015, while in 2013 it was estimated at $\$ 16,000$ billion; the increase in the period 2013-2015 is approximately 37\% [4].

The most significant investment approaches for SRI are:

(1) Exclusions: excluding investments in businesses and organizations (essentially private ones) operating in the so-called "controversial" industries (tobacco; alcohol; pornography; weapons);

(2) Norms-Based Screening: choosing investments in organizations (essentially public ones) that, as part of their own activities, cohere with the international regulations and standards;

(3) Engagement/Voting: choosing investments in businesses and organizations (public and private) that include forms of active shareholder participation in decision-making;

(4) ESG Integration: explicit inclusion by asset managers of ESG risks and opportunities into traditional financial analysis and investment decisions based on a systematic process and appropriate research sources;

(5) Best in Class: an approach where leading or best-performing investments within a universe, category, or class are selected or given weight based on ESG criteria;

(6) Sustainability-Themed: investment in themes or assets linked to the development of sustainability. Thematic funds focus on specific or multiple issues related to ESG; 
(7) Impact Investment: choosing "responsible" investments in businesses and organizations (public and private) that, as part of their activities, alongside a financial income, are able to generate a beneficial (and measurable) social and/or environmental impact.

From 2013 to 2015 there has been an evolution of SRI strategies and continuous growth, with significant increases of the Compound Annual Growth Rate (CAGR) and, more specifically, exclusion $+22 \%$; norms based-screening $+18 \%$; engagement and voting $+14 \%$, ESG integration $+18 \%$, best in class $+18 \%$, sustainability-themed $+57 \%$, while impact investing is still the fastest growing strategy, at $120 \%$ CAGR [4].

During the last few years, the number of investors in SRIs has expanded, including institutional (corporate, insurance, asset managers); qualified (corporate, non-governmental and/or para-governmental organizations), and common (small, small and medium companies). The growing attractiveness of these forms of investment has led to the establishment of a significant number of Funds geared towards SRIs referred to as "socially-responsible funds" [13]. In general terms, socially-responsible funds allocate capital (to public and private businesses and organizations) both on the basis of financial profit (in line with the conventional processes of financial assessment) and with a view to the satisfaction of social and environmental demands.

Only in Europe, during the period 1999-2015, was there an increase of about $800 \%$ in socially-responsible funds (from 158 socially-responsible funds in 1999 to 1204 socially-responsible funds in 2015). As a result the total of financial Assets Under Management (AUM) amounted to around 372 billion euro in 2015 , with a growth of about $56 \%$ compared to the previous two years [14]. Socially-responsible funds collected 372 billion euro representing about $2 \%$ of the world's financial mass related to SRIs [14]. SRIs within socially-responsible funds (SRIF/s) have however a relevant financial consistency and are expected to increase. The growth of SRIFs is also witnessed through the activity of major market players who have considerably increased the SRIFs within their assets under management for the 2013-2015 period: for example in 2015, Candriam Investor Group, 21 billion (21\% total AUM); Natixis Asset Management launched Mirova, with 46 billion of AUM (6\% total Natixis AUM); Northern Trust 62 billion (7\% total AUM) [4]. The wide consistency of SRIFs involves a variety of operational possibilities (policy areas), which also include RE (see Section 2).

Buying into RE can provide investors with additional guarantees which generate positive environmental (reduced consumption of resources/energy) and social (employment, security, well-being, people relationships) effects. Green building may also have an added value compared to traditional building. Thus, RE may represent an interesting sector for SRIFs, in relation to some specific approaches to SRIs (ESG integration, sustainability-themed, impact investment) and sustainable development goals $[15,16]$. Introducing measures and tools which guarantee sustainability can also increase the RE value $[17,18]$. In recent years building construction in many Western countries has exceeded and/or been distant from the "real" market (an effect caused by the global crisis). However there are still various opportunities for sustainable RE development related to: an aging population; the failure of urban decentralization models; making savings in property management costs and, more generally, through the environmental sustainability of interventions and urban ecology.

In this context, among RE operators there is a growing awareness of having to formulate RE proposals and scenarios that do not have profitability as their only criteria. The common objective is growth based on "sustainable" development from an environmental point of view (the safeguarding of increasingly "rare" resources, such as land, energy, and natural features) [19], as well as from a social one (protecting the population and raising its level of well-being). They pertain to what is known as "ethical finance", instead of mere "speculative" investment. Many RE trusts and funds claim to have increasing levels of sustainability in their portfolios. From corporate social responsibility reporting to various certifications, the list demonstrating their level of sustainability is extensive [20]. Even between different players operating within the field of RE, it has now been agreed that the objectives of RE initiatives should be relating to "ethical finance". In fact, this area is poorly covered by SRIFs, with 
initiatives aimed at the creation of housing for vulnerable groups [21-24] on both greenfield and brownfield sites.

Among the causes of the only partial inclusion of RE in SRIFs it is recognized that: (i) the "mistrust" results from previous events (crisis in sub-prime and the RE bubble) that caused the current global financial and economic crisis [25-27]; (ii) the "elusive" assessment approach used by socially-responsible funds to identify the expected returns from investment in relation to possible and sudden changes in the housing market. Such an approach does not provide adequate means to understand the other effects (social and environmental) involved in RE initiatives [1,28-31].

Different assessment procedures are generally applied during the evaluation of SRIs in order to measure the returns associated with ESG investment factors [32]. In addition to traditional economic indicators (economic net present value and economic internal rate of return), Social Return On investment (SROI) is used to assess the relationship between economic value and monetary Investment, including several ESG indicators [33]. Therefore, further growth of SRIFs may concern RE but the reporting and evaluation standards demanding major transparency and accountability must increase [4]. SRIFs in RE require joint assessment of (traditional) financial risk, as well as non-monetary aspects related to ESG factors employing the assessment tools also used in the ordinary management of socially-responsible funds.

In decision-making problems where a variety of aspects and effects have to be simultaneously considered, the use of Multi-Criteria Decision Analysis (MCDA) tools is well established for the evaluation of both financial, risk-related [34], and ESG aspects at the same time, and also in the implementation of RE initiatives [35-39]. This paper aims to propose an assessment procedure, structured on a MCDA model, that makes it possible to verify when and if an RE initiative, which is to be included in the investment basket of an socially-responsible funds, may be considered, given its properties, an SRIF or a traditional type investment.

Hereinafter the present paper will be proceed as follows. Firstly with the analysis of a significant sample of 40 socially-responsible funds and of the related regulatory framework SRIs in order to determine assessment criteria, sub-criteria, indicators, relevance, and features to assess an investment in RE (both SRIF and traditional) (Section 2). Secondly we will examine the selection of the most suitable MCDA technique on which to base the assessment procedure (Section 3). Finally the phases and the mathematical/assessment operations used in the assessment procedure proposed will be described, together with their application in a specific case study of a social housing project in the municipality of Anguillara Sabazia (Rome) (Section 4). The obtained results will then be summarized (Section 5).

\section{Regulatory Framework for the SRIs/Socially-Responsible Funds, Properties, and Criteria for SRIF Assessment}

Before 2014, the Member States of the European Community did not have any kind of common regulatory framework regarding SRIs and socially-responsible funds. In general, every country had "soft laws", with no direct binding effect, but flexible and capable of adapting to the rapid developments that characterize certain aspects of economic or social life [2]. The European Directive (2014/95/EU) [40] which amended Directive 2013/34/EU [41] "as regards disclosure of non-financial and diversity information by certain large undertakings and groups" is aimed at improving transparency in financial reporting. Among the objectives of this Directive is that of increasing the relevance, the consistency and the comparability of the information disclosed by certain activities and groups across the European Union. Member States should have brought into force the laws, regulations and administrative provisions necessary to comply with this Directive by 6 December 2016. A review of the legal and regulatory framework regarding SRIs in the principle countries of Europe has been carried out in the European SRI Study [4]. This study highlights the growing attention in this area and the first regulatory guidelines on SRIs and SRIFs. However, through 
the European SRI study [4] it has been shown that the regulatory frameworks of these main European countries are not designed to adapt specific references and assessment tools to the features of SRIFs.

In this paper, in order to identify the features and assessment criteria of SRIF in RE an analysis has been carried out of the aspects (refer to approaches shown in Section 1) and procedures used to choose investments. The study looks at a sample (40) of international socially-responsible funds that, in allocating their own resources, offer opportunities for subscription to investors in Italy. The significant sample of 40 socially-responsible funds is identified by the report entitled Investimenti socialmente responsabili: la mappa dei fondi [42].

On the site 34 international socially-responsible funds are listed as offering the possibility of subscription to investors in Italy. This list of socially-responsible funds has been supplemented with a further six socially-responsible funds of the asset-management company Investire (Rome, Italy), identified through an online survey looking at the websites of the leading asset management companies operating in Italy. The analysis (Table 1) shows that the most popular are those involving environmental and social enterprises. Only a restricted number of socially-responsible funds (6) include, among their social SRIFs, social housing (SH) initiatives.

Within savings management, traditional investments in RE are generally connected to "facility management" activities and to "refurbishment and urban development" without limits or restrictions relating to the size and type of the initiative; SRIFs in the same sector (RE), based on the analysis carried out, are limited to $\mathrm{SH}$ initiatives. In both cases (traditional investments and $\mathrm{SH}$ ), for all the players present in the RE market, the allocation of capital in initiatives/companies is typically approved in relation to financial income indicators as well as risk assessments (see Section 1).

An in-depth examination of the socially-responsible funds whose investment sectors include $\mathrm{SH}$ highlights, as already mentioned in Section 1, demonstrates that the choice of SRIFs does not rely purely on the financial income indicators and risk assessments, but also on the non-monetary effects of the initiatives connected with them. This includes the method by which the housing asset is accessed (purchase or rental) and the management sustainability for the various segments of the population (including the weakest); employment increase; support for education and professional training. 
Table 1. Analysis of socially-responsible funds.

\begin{tabular}{|c|c|c|c|c|c|c|c|c|}
\hline & & \multicolumn{4}{|c|}{ Environmental } & \multicolumn{3}{|c|}{ Social } \\
\hline & & $\begin{array}{c}\text { Water } \\
\text { Optimization }\end{array}$ & Wastes & Agritech & $\begin{array}{c}\text { Renewable } \\
\text { Energies }\end{array}$ & Edutech & Smartech & $\begin{array}{c}\text { Social } \\
\text { Housing }\end{array}$ \\
\hline \multirow{16}{*}{ Equity } & Aberdeen Global-Responsible World Equity Fund & $X$ & $X$ & $\mathrm{X}$ & $X$ & & & \\
\hline & Cs Etf on Cs Global Alternative Energy & & & & $X$ & & $X$ & \\
\hline & Dexia Equities L Sustainable Emerging Markets & & & $x$ & & $X$ & $x$ & \\
\hline & Dexia Equities L Sustainable Emu & & & $X$ & & $X$ & & \\
\hline & Dexia Equities L Sustainable Green Planet & & $X$ & & $X$ & & & \\
\hline & Dexia Sustainable Europe & $X$ & $X$ & & & & & \\
\hline & Dexia Sustainable World & & $X$ & & & & & \\
\hline & Echiquier Major & $X$ & & & $X$ & & & \\
\hline & Etica Azionario & & $x$ & $x$ & $x$ & $x$ & $x$ & \\
\hline & Eurizon Azionario Internazionale Etico & & & & $x$ & $x$ & $x$ & \\
\hline & iShares Dow Jones Eurozone Sustainability Screened & $x$ & & $x$ & & & & \\
\hline & Nordea 1-Climate and Environment Equity Fund & & $X$ & & $x$ & & $x$ & \\
\hline & Nordea 1-Emerging Stars Equity Fund & & & $x$ & & & $x$ & \\
\hline & Pioneer Funds-Global Ecology & $X$ & $X$ & & $X$ & $X$ & $X$ & \\
\hline & Swisscanto (LU) Equity Fund Climate Invest J & & & & $X$ & & $X$ & \\
\hline & Swisscanto (LU) Equity Fund Water Invest J & $\mathrm{X}$ & $x$ & & & & & \\
\hline \multirow{5}{*}{$\begin{array}{c}\text { Balanced } \\
\text { and } \\
\text { flexible }\end{array}$} & Aureo Finanza Etico & & & & & $x$ & $x$ & \\
\hline & Dexia Sustainable High & & & $X$ & $\mathrm{X}$ & & $X$ & \\
\hline & Dexia Sustainable Low & & $x$ & & & & & \\
\hline & Dexia Sustainable Medium & & & & $x$ & & $x$ & \\
\hline & Etica Bilanciato & $x$ & & $x$ & $x$ & & & \\
\hline \multirow{9}{*}{ Bond } & Dexia Bonds Sustainable Euro Government & $x$ & & & & & $X$ & \\
\hline & Dexia Money Market Euro Sustainable & & & $x$ & & $x$ & $x$ & \\
\hline & Dexia Sustainable Euro Bonds & $x$ & & & & & & \\
\hline & Dexia Sustainable Euro Corporate Bonds & & & & $x$ & $x$ & & \\
\hline & Dexia Sustainable Euro Short Term & & & & $x$ & $x$ & & \\
\hline & Etica Obbligazionario Misto & $x$ & $x$ & $x$ & $x$ & & $x$ & \\
\hline & Etica Obbligazionario Misto Breve Termine & & & & & $x$ & & \\
\hline & Eurizon Diversificato Etico & $x$ & & & & & $x$ & \\
\hline & Eurizon Obbligazionario Etico & & & & $X$ & & $X$ & \\
\hline
\end{tabular}


Table 1. Cont.

\begin{tabular}{|c|c|c|c|c|c|c|c|}
\hline & \multicolumn{4}{|c|}{ Environmental } & \multicolumn{3}{|c|}{ Social } \\
\hline & $\begin{array}{c}\text { Water } \\
\text { Optimization }\end{array}$ & Wastes & Agritech & $\begin{array}{c}\text { Renewable } \\
\text { Energies }\end{array}$ & Edutech & Smartech & $\begin{array}{c}\text { Social } \\
\text { Housing }\end{array}$ \\
\hline Euro Corporate Etico a distribuzione & & & $X$ & $x$ & & & \\
\hline Investire FASP & & & & & & & $x$ \\
\hline Investire FERSH & & & & & & & $x$ \\
\hline Investire FHCR & & & & & & & $x$ \\
\hline Investire Fil 1 & & & & & & & $X$ \\
\hline Investire FPSH & & & & & & & $x$ \\
\hline Investire IBI & & & & & & & $x$ \\
\hline Nordfondo Etico & $x$ & $x$ & $x$ & & & $x$ & \\
\hline Pioneer Obbligazionario & $x$ & & $x$ & & $x$ & $x$ & \\
\hline
\end{tabular}


To assess a SRIF in RE, it is necessary to consider the criteria, sub-criteria, indicators, relevance, and features that show the difference between a traditional initiative and a socially responsible one. This is in order to recognize when a RE initiative is an SRIF instead of traditional. Since it is deemed that socially-responsible funds may deal with every kind of RE initiative, not only $\mathrm{SH}$, a number of: (i) criteria, (ii) sub-criteria and indicators, including their relevance, and (iii) thresholds that the indicators must attain (properties) in order to be considered "impact" or "traditional," were defined in consideration of the following (Table 2):

- assessment criteria and sub-criteria used by the six socially-responsible funds among those considered, whose investment sectors include SH (sub-criteria 1, 2, 3, 4, 5, 6, 8, 9, 10);

- $\quad$ assessment criteria and sub-criteria available from European Directive 2014/95/EU [40] related to regulations and "good practices" (sub-criteria 7, 14, 15);

- assessment criteria taken from "A Guide to Social Return on Investment" [33] and which are relevant for the SROI calculation (sub-criteria 11, 12, 13, 18);

Urban quality assessment criteria and sub-criteria are more pertinent to the purposes of this paper, proposed by AUDIS Associazione Aree Urbane Dismesse [43]. These criteria were formulated with the aim of identifying the aspects of settlement transformation able to guarantee the quality of the city and of the life of its inhabitants (sub-criteria 16,17, 19). The 19 sub-criteria (Table 2) were defined to: (i) take into account all the main aspects which characterize an RE initiative [44]; and (ii) enabling quick and effective implementation of the MCDA. Table 2 also indicates the properties that, if considered together, represent the necessary conditions for an investment to be considered acceptable as a "traditional investment" or an SRIF. Such features, when compared to the data of the initiative to be assessed, make it possible to outline two solutions of reference: (i) a traditional solution (TS); (ii) a socially-responsibility solution (SRS). These are to be used as the alternatives in the assessment procedure.

The properties of the investments used were decided: (i) for the traditional investments, by means of the performance levels ordinarily detectable in initiatives in the RE market; and (ii) for the SRIF, by interpreting the performance of the principles underpinning this type of approach, which have been deduced from the analysis of the 40 socially-responsible funds. It should be taken into consideration that if an initiative does not present a financial income which is satisfactory for ordinary market rates, it cannot be financed, neither by socially-responsible funds, nor by the usual channels of financing for development and refurbishment processes in the RE market (such as banks, investment funds, club deals, and crowd-funding). 
Table 2. Criteria, sub-criteria, indicators, relevance, and features in order to assess a traditional investment and a socially-responsible investment in RE.

\begin{tabular}{|c|c|c|c|c|c|c|c|c|}
\hline Criteria (C) & & Sub-Criteria (SC) & Indicators (I) & $\begin{array}{c}\text { Objective } \\
\text { Functions (OF) }\end{array}$ & $\begin{array}{c}\text { Relevanc } \\
\text { (SRIF) }\end{array}$ & $\begin{array}{c}\text { Features } \\
\text { (SRIF) }\end{array}$ & $\begin{array}{l}\text { Relevanc } \\
\text { (TI) }\end{array}$ & $\begin{array}{c}\text { Features } \\
(\mathrm{TI})\end{array}$ \\
\hline \multirow{5}{*}{ Financial } & 1 & Profitability of initiative & Internal Rate Return & $\uparrow$ & $\mathrm{H}$ & $8 \%$ & $\mathrm{VH}$ & $10 \%$ \\
\hline & 2 & $\begin{array}{l}\text { Solidity of builfing as guarantee of } \\
\text { investment }\end{array}$ & $\begin{array}{l}\text { Stability/increase/decrease annual } \\
\text { trend of market values area and/or } \\
\text { property covered by the initiative }\end{array}$ & $\uparrow$ & $\mathrm{H}$ & Stability & M & Stability \\
\hline & 3 & Tax benefits & Tax/no tax exemption on trading profits & $\uparrow$ & $\mathrm{VH}$ & No tax & M & Tax \\
\hline & 4 & Financial benefits for the final user & $\%$ discount of mortgage/rent & $\uparrow$ & $\mathrm{H}$ & $33 \%$ & $\mathrm{~L}$ & $0 \%$ \\
\hline & 5 & $\begin{array}{l}\text { Product's ability to meet the } \\
\text { segmentations of the market } \\
\text { demand }\end{array}$ & Qualitative (VH, H, M, L, VL) & $\uparrow$ & $\mathrm{M}$ & High & $\mathrm{M}$ & High \\
\hline \multirow{8}{*}{ Social } & 6 & Sustainability during operating & $\begin{array}{l}\% \text { income (max for maximum annual } \\
\text { family subsidized) housing for expense } \\
\text { management }\end{array}$ & $\uparrow$ & $\mathrm{H}$ & $10 \%$ & $\mathrm{~L}$ & $15 \%$ \\
\hline & 7 & Advantages of the urban fabric & Sqm of urban standard per capita & $\uparrow$ & M & 30 & M & 18 \\
\hline & 8 & Stable employment & $\begin{array}{l}\% \text { annual staff permanently } \\
\text { employed/unemployed territorial area } \\
\text { in which the initiative has repercussions }\end{array}$ & $\uparrow$ & $\mathrm{M}$ & $0,05 \%$ & VL & $0 \%$ \\
\hline & 9 & Temporary employment & $\begin{array}{l}\% \text { annual staff RE } \\
\text { employed/unemployed RE territorial } \\
\text { area in which the initiative has } \\
\text { repercussions }\end{array}$ & $\uparrow$ & $\mathrm{M}$ & $1,00 \%$ & $\mathrm{~L}$ & $0 \%$ \\
\hline & 10 & Facilitations vulnerable population & $\begin{array}{l}\% \text { of non-repayable contribution to } \\
\text { housing price }\end{array}$ & $\uparrow$ & $\mathrm{H}$ & $20 \%$ & M & $0 \%$ \\
\hline & 11 & Reduced social isolation & $\begin{array}{l}\text { Qualitative about involvement of local } \\
\text { community in organisation's activities } \\
(\mathrm{VH}, \mathrm{H}, \mathrm{M}, \mathrm{L}, \mathrm{VL})\end{array}$ & $\uparrow$ & $\mathrm{H}$ & High & $\mathrm{L}$ & Low \\
\hline & 12 & Improve accesse to local service & $\begin{array}{l}\text { Qualitative about take-up of those } \\
\text { services, and by whom (VH, H, M, L, VL) }\end{array}$ & $\uparrow$ & $\mathrm{H}$ & High & $\mathrm{L}$ & Low \\
\hline & 13 & $\begin{array}{l}\text { Improved behaviour (support for } \\
\text { education/vocational training) }\end{array}$ & Present/absent & $\uparrow$ & M & Present & VL & Absent \\
\hline
\end{tabular}


Table 2. Cont.

\begin{tabular}{|c|c|c|c|c|c|c|c|}
\hline Criteria (C) & Sub-Criteria (SC) & Indicators (I) & $\begin{array}{c}\text { Objective } \\
\text { Functions (OF) }\end{array}$ & $\begin{array}{l}\text { Relevanc } \\
\text { (SRIF) }\end{array}$ & $\begin{array}{c}\text { Features } \\
\text { (SRIF) }\end{array}$ & $\begin{array}{l}\text { Relevanc } \\
\text { (TI) }\end{array}$ & $\begin{array}{l}\text { Features } \\
\text { (TI) }\end{array}$ \\
\hline \multirow{6}{*}{ Environmental } & 14 Land use & $\begin{array}{l}\% \text { free areas compared to total area of } \\
\text { intervention }\end{array}$ & $\downarrow$ & $\mathrm{VH}$ & $0 \%$ & $\mathrm{~L}$ & $70 \%$ \\
\hline & 15 Safeguard environment resources & $\begin{array}{l}\text { Qualitative about material consumption } \\
\text { (VH, H, M, L, VL) }\end{array}$ & $\downarrow$ & $\mathrm{H}$ & Low & $\mathrm{L}$ & Low \\
\hline & 16 Urban fabric requalification & $\begin{array}{l}\text { \% Degraded areas and/or abandoned } \\
\text { rehabilitated than those to be } \\
\text { redeveloped within the territory in } \\
\text { which the initiative has influences }\end{array}$ & $\uparrow$ & $\mathrm{L}$ & $10 \%$ & VL & $0 \%$ \\
\hline & 17 Environment perceptive quality & Square meters of green area per capita & $\uparrow$ & $\mathrm{H}$ & 18 & M & 9 \\
\hline & 18 Increase in recycling & $\begin{array}{l}\text { Amount of waste going to landfill (\% on } \\
\text { the total) }\end{array}$ & $\downarrow$ & $\mathrm{H}$ & $25 \%$ & $\mathrm{~L}$ & $100 \%$ \\
\hline & 19 Preservation of resources & $\begin{array}{l}\text { Compliance/non-compliance with the } \\
\text { LEED parameters }\end{array}$ & $\uparrow$ & M & $\mathrm{A}$ & M & B \\
\hline
\end{tabular}




\section{Selection of the MCDA Techniques Used to Structure the Assessment Procedure}

The MCDA techniques most frequently used in praxis are: weighted sum model (WSM); analytic hierarchy process (AHP); ELimination Et Choix Traduisant la REalitè (ELECTRE); EVAluation of MIXed criteria (EVAMIX), and the Technique for Order Preference by Similarity to Ideal Solution (TOPSIS) [45]. To make a choice between these techniques different elements have to be considered $[46,47]$ :

The main features (Table 3) of each technique in order of:

1. (a) the relationship between elements of the matrix on which depends the possibility of determining the synthesis results of each alternative in the evaluation (quantitative or just majority/minority);

1. (b) typology of the sub-criteria (quantitative; qualitative; mixed);

1. (c) time available for the implementation of the evaluation procedure (long, medium, short);

1. (d) level of difficulty in changing the template syntax (high, medium, low);

The requirements related to the procedure to assess a SRIF in RE must allow:

2. (a) the initiative(s) to be compared with two reference solutions SRS and TS, the set of alternatives under assessment consists, therefore, of the reference solutions and the real initiative(s);

2. (b) the evaluation of the initiative(s) considering both quantitative and qualitative criteria.

Table 3. Features of the main MCDA techniques.

\begin{tabular}{|c|c|c|c|c|c|c|}
\hline \multirow{2}{*}{ Aspects } & \multirow{2}{*}{$\begin{array}{l}\text { Criteria for } \\
\text { Cataloging Features }\end{array}$} & \multicolumn{5}{|c|}{ Features } \\
\hline & & WSM & AHP & EVAMIX & ELECTRE & TOPSIS \\
\hline $\begin{array}{l}\text { 1. (a) Relationship between elements of } \\
\text { the matrix from which it depends the } \\
\text { possibility of determining the synthesis } \\
\text { results of each evaluation alternative }\end{array}$ & $\begin{array}{l}\text { Quantitative (Q) } \\
\text { Majority/minority (M) }\end{array}$ & Q & M & Q & Q & Q \\
\hline 1. (b) Typology of sub-criteria & $\begin{array}{l}\text { Quantitative (QUAN) } \\
\text { Qualitative (QUAL) } \\
\text { Mixed (M) }\end{array}$ & M & M & M & QUAN & M \\
\hline $\begin{array}{l}\text { 1. (c) Time available for the } \\
\text { implementation of the evaluation } \\
\text { procedure }\end{array}$ & $\begin{array}{l}\text { Long (L) Medium (M) } \\
\text { Short (S) }\end{array}$ & S & $\mathrm{L}$ & M & $\mathrm{L}$ & M \\
\hline $\begin{array}{l}\text { 1. (d) Level of difficulty in changing the } \\
\text { template syntax }\end{array}$ & $\begin{array}{l}\text { High }(\mathrm{H}) \text { Medium }(\mathrm{M}) \\
\text { Low }(\mathrm{L})\end{array}$ & $\mathrm{L}$ & $\mathrm{H}$ & M & $\mathrm{H}$ & $\mathrm{M}$ \\
\hline
\end{tabular}

The analysis of the features of these techniques in relation to the requirements of the assessment allows us to identify the characteristics required by the technique to be used in the assessment procedure, that is:

- the possibility of a quantitative comparison among the elements of the matrix; in fact, the possibility of using comparisons of majority/minority should be excluded because the differences between the alternatives (both real initiative/s and reference solutions) under assessment should be quantitatively defined;

- the joint management of assessment sub-criteria, both quantitative and qualitative; the possibility of adapting to specific assessment needs, in this case related to the ability to compare the reference solutions and the real initiative(s).

The choice is focused on the technique that is most useful in meeting the requirements of the assessment: among the identified techniques, WSM and TOPSIS meet the requirements. The latter (TOPSIS) is able to generate more accurate and useful results for this assessment as it provides a distance from the ideal solution and also between the alternatives being considered; in this case, the RE initiative being assessed and the two reference solutions (see Section 4). This method is also quickly and easily implementable even in the absence of a decision aid specialist. 


\section{The Assessment Procedure Applied to a Case Study}

As already mentioned, the proposed assessment procedure has been created in order to recognize when a RE initiative is a SRIF enabling us to consider whether or not it can be included in the investment basket within a socially-responsible fund. The proposed assessment procedure provides an operational declination using the TOPSIS method which can effectively organize the initiative(s) being assessed with regard not only to the ideal and non-ideal solutions (that TOPSIS is able to create), including those that are hypothetical and unlikely to be repeated, but also with regard to viable reference solutions TS and SRS (see Section 3). With regard to the initiative(s) to be assessed, the specific parameters which define them from the point of view of what is acceptable for respectively traditional investments and SRIFs must be defined (see Section 2). In the next section, the proposed assessment procedure will be described in conjunction with its application to the case study-the social housing initiative Piano di Zona Le Fontane in the municipality of Anguillara Sabazia (RM) - as follows:

1. Analysis of the initiative(s) to be assessed;

2. Construction and compilation of the assessment matrix;

3. Normalization of the assessment matrix;

4. Definition and attribution of weights to the assessment matrix; and

5. Aggregation of data and results of the assessment.

\subsection{Analysis of the Initiative(s) Being Assessed}

The analysis of the initiative(s) to be assessed has been done through examination of the available documentation (technical and descriptive documents, administrative records on the adoption and approval procedures) and is aimed at extrapolating the main data regarding the initiative's general and dimensional aspects (Table 4 ).

Table 4. Data of Piano di Zona Le Fontane.

\begin{tabular}{ccc}
\hline General aspects & Measure & Data \\
\hline Intervention area & $\mathrm{sqm}$ & 113,000 \\
Building potential & $\mathrm{cm}$ & 95,350 \\
residential & $\mathrm{cm}$ & 75,300 \\
non residential & $\mathrm{cm}$ & 20,050 \\
New abitants & $\mathrm{n}$. & 1060 \\
Land for building & $\mathrm{sqm}$ & 46,396 \\
Land for standard & sqm & 51,357 \\
per capita & sqm & 48 \\
Public road & sqm & 15,247 \\
\hline Private buildings & type & Residential palaces; villas \\
\hline Public buildings & type & - \\
Building features & & Energetic class "A" \\
Profitability of initiative & $8.12 \%$ \\
Trend market value in last 5 year & & $-35 \%$ \\
Tax benefits & & None \\
Type of final users & & Vulnerable part of popolation \\
\hline Type of housing demand in the Municipality of Ladispoli & & First house principally \\
\hline Costs (estimated) for operating (maintenance, utilities) per year & $€$ & 3400 \\
\hline New permanent jobs & $\mathrm{n}$. & 55 \\
\hline Unegional non-repayable contribution & $€$ & 1700 \\
\hline
\end{tabular}

These data must be appropriately processed in order to determine the impact related to the financial, social, and environmental sub-criteria, which is to be inserted into the assessment matrix [48]. 
Piano di Zona Le Fontane is an urban program which pursues the objective of increasing SH units in the Municipality of Anguillara Sabazia (RM) aiming at satisfying the demand for housing of the less affluent elements of the resident population in the municipality. This program also seeks to reorganize the peripheral urban setting between Cesano di Roma (RM) and the urban centers situated on Via Anguillarese. This setting is currently (2016) a suburban area devoid of services and public facilities. The initiative includes, in addition to the residential aspect, a retirement home for the elderly and commercial services for the entire district. The initiative benefits from a public grant of about $€ 5$ million, for the building of 260 housing units within small buildings and villas, linked to a new road network and provided with green spaces. In addition to the housing grant of approximately $€ 20,000$, the sale price of the residential units is regulated in alignment with the maximum total set for edilizia agevolata (assisted building) by the Lazio Region (about $€ 2000 / \mathrm{m}^{2}$ ).

\subsection{Construction and Filling of the Assessment Matrix}

Regarding the assessment matrix (two-dimensional $(\mathrm{SC} \times \mathrm{A})$, in which one dimension is represented by the $\mathrm{SCj}$ sub-criteria $(j=1, \ldots, j)$ and the other by the alternative Ai (initiative(s) to be assessed and solutions of reference) $(i=1, \ldots, i))$ the criteria, sub-criteria, and indicators defined in Section 2 (Table 2) have been used.

The assessment matrix has been completed by inserting the impacts $i(S C n)$ (which express the performance) of the initiative Piano di Zona Le Fontane and the two reference solutions, TS and SRS (Table 5, part a).

\subsection{Normalization of the Assessment Matrix}

To proceed with the comparison of the data entered in the assessment matrix, it is necessary for it to be "normalized".

The data have been made uniform and comparable by assigning each impact $i(S C n)$ a coefficient $c(S C n)$.

Among the different functions that were applicable (row maximum, row minimum, ideal value, average value, interval standardization, additive constraint) we have decided to apply the linear function "row maximum" that allows the coefficients for each sub-criteria to be determined by comparing, the impact of each alternative to the impact which has the best performance (Table 5, part b). 
Table 5. Normalized and weighted assessment matrix.

\begin{tabular}{|c|c|c|c|c|c|c|c|c|c|c|c|c|c|}
\hline \multicolumn{6}{|c|}{ Part a } & \multirow{2}{*}{\multicolumn{3}{|c|}{$\begin{array}{c}\text { Part b } \\
\text { Normalized Impacts }\end{array}$}} & \multicolumn{4}{|c|}{ Part c } & \multirow{3}{*}{$\begin{array}{c}\text { Part d } \\
\text { Non-Ideal Sol }\end{array}$} \\
\hline \multirow{2}{*}{ SC } & \multirow{2}{*}{ W } & \multirow{2}{*}{ OF } & \multirow{2}{*}{ SH (Piano di Zona Le Fontane) } & \multirow{2}{*}{ SRS (Ipotetic Solution 1) } & \multirow{2}{*}{ TS (Ipotetic Solution 2) } & & & & \multicolumn{3}{|c|}{ Normalized and Weighted Impacts } & \multirow{2}{*}{ Ideal Sol. } & \\
\hline & & & & & & SH & SRS & TS & SH & SRS & TS & & \\
\hline 1 & 9.09 & $\uparrow$ & $8.12 \%$ & $8 \%$ & $10 \%$ & 0.8120 & 0.8000 & 1.0000 & 7.3818 & 7.2727 & 9.0909 & 9.0909 & 7.2727 \\
\hline 2 & 6.49 & $\uparrow$ & Decrease & Stability & Stability & 0.0000 & 0.5000 & 0.5000 & 0.0000 & 3.2468 & 3.2468 & 3.2468 & 0.0000 \\
\hline 3 & 7.79 & $\uparrow$ & No tax & No tax & Tax & 0.0000 & 1.0000 & 0.0000 & 0.0000 & 7.7922 & 0.0000 & 7.7922 & 0.0000 \\
\hline 4 & 5.19 & $\uparrow$ & 0 & $33 \%$ & $0 \%$ & 1.0000 & 0.8000 & 0.8000 & 5.1948 & 4.1558 & 4.1558 & 5.1948 & 4.1558 \\
\hline 5 & 5.19 & $\uparrow$ & $\mathrm{H}$ & $\mathrm{H}$ & $\mathrm{H}$ & 0.8000 & 0.8000 & 0.8000 & 4.1558 & 4.1558 & 4.1558 & 4.1558 & 4.1558 \\
\hline 6 & 5.19 & $\uparrow$ & $12 \%$ & $10 \%$ & $15 \%$ & 1.2000 & 1.0000 & 1.5000 & 6.2338 & 5.1948 & 7.7922 & 5.1948 & 7.7922 \\
\hline 7 & 5.19 & $\uparrow$ & 48 & 30 & 18 & 1.6000 & 1.0000 & 0.6000 & 8.3117 & 5.1948 & 3.1169 & 5.1948 & 3.1169 \\
\hline 8 & 2.60 & $\uparrow$ & $0.028 \%$ & $0.05 \%$ & $0 \%$ & 1.0000 & 1.7857 & 0.0000 & 2.5974 & 4.6382 & 0.0000 & 2.5974 & 0.0000 \\
\hline 9 & 3.90 & $\uparrow$ & $0.40 \%$ & $1.00 \%$ & $0 \%$ & 0.0000 & 1.0000 & 0.0000 & 0.0000 & 3.8961 & 0.0000 & 3.8961 & 0.0000 \\
\hline 10 & 6.49 & $\uparrow$ & $10 \%$ & $20 \%$ & $0 \%$ & 1.0000 & 2.0000 & 0.0000 & 6.4935 & 1.9870 & 0.0000 & 6.4935 & 12.9870 \\
\hline 11 & 5.19 & $\uparrow$ & $\mathrm{M}$ & $\mathrm{H}$ & $\mathrm{L}$ & 0.6000 & 0.8000 & 0.4000 & 3.1169 & 4.1558 & 2.0779 & 4.1558 & 2.0779 \\
\hline 12 & 5.19 & $\uparrow$ & M & $\mathrm{H}$ & $\mathrm{L}$ & 0.6000 & 0.8000 & 0.4000 & 3.1169 & 4.1558 & 2.0779 & 4.1558 & 2.0779 \\
\hline 13 & 2.60 & $\uparrow$ & Absent & Present & Absent & 0.0000 & 1.0000 & 0.0000 & 0.0000 & 2.5974 & 0.0000 & 2.5974 & 0.0000 \\
\hline 14 & 6.49 & $\downarrow$ & $45 \%$ & $0 \%$ & $70 \%$ & 0.5500 & 1.0000 & 0.3000 & 3.5714 & 6.4935 & 1.9481 & 6.4935 & 1.9481 \\
\hline 15 & 5.19 & $\downarrow$ & $\mathrm{M}$ & L & L & 0.6000 & 0.4000 & 0.4000 & 3.1169 & 2.0779 & 2.0779 & 3.1169 & 2.0779 \\
\hline 16 & 1.30 & $\uparrow$ & $0 \%$ & $10 \%$ & $0 \%$ & 0.0000 & 1.0000 & 0.0000 & 0.0000 & 1.2987 & 0.0000 & 1.2987 & 0.0000 \\
\hline 17 & 6.49 & $\uparrow$ & 25 & 18 & 9 & 1.0000 & 0.7200 & 0.3600 & 6.4935 & 4.6753 & 2.3377 & 6.4935 & 2.3377 \\
\hline 18 & 5.19 & $\downarrow$ & $25 \%$ & $25 \%$ & $100 \%$ & 1.0000 & 1.0000 & 0.0000 & 5.1948 & 5.1948 & 0.0000 & 5.1948 & 0.0000 \\
\hline 19 & 5.19 & $\uparrow$ & $\mathrm{H}$ & $\mathrm{H}$ & $\mathrm{L}$ & 0.8000 & 0.8000 & 4.0000 & 4.1558 & 4.1558 & 20.7792 & 4.1558 & 20.7792 \\
\hline
\end{tabular}




\subsection{Definition and Attribution of Weights to the Assessment Matrix}

A weight obtained by the pair comparison method on the basis of the average relevance assigned to the sub-criteria, based on the importance given them in the two hypotheses of reference, has then been given to each of the sub-criteria $S C n$.

Normalized and weighted coefficients $w c(S C n)$ have been obtained by multiplying each of the input data transformed into coefficients, as present in the assessment matrix $c(\mathrm{SCn})$, by the respective weights $w(S C n)$, (Table 5, part c) using the formula:

$$
w c(S C n)=c(S C n) \times w(S C n)
$$

\subsection{Aggregation of the Data and Results of the Assessment}

Through the aggregation of data it is possible:

- to identify the solution:

(i) Ideal (Table 5, part d), by selecting, for each sub-criterion, the best impact i(SCn) recorded among the various alternatives (initiative(s) to be assessed and the TS and IS solutions of reference), following the formula:

$$
i(S C)^{+}=\max i(S C x ; A y) \text { dove } x=S C 1, S C 2, \ldots, S C n ; y=A 1, A 2, \ldots A n
$$

(ii) Non-ideal (Table 5, part d), by selecting, for each sub-criterion, the worst impact recorded among the various alternatives, following the formula:

$$
i(S C)^{-}=\min i(S C x ; A y) \text { dove } x=S C 1, S C 2, \ldots, S C n ; y=A 1, A 2, \ldots A n
$$

- $\quad$ estimate the Euclidean distance of each $i$-th alternative to the solution:

(i) Ideal, using the formula:

$$
d_{A i}^{+}=\sqrt{\sum_{x=1}^{n}\left[i\left(S C x_{A i}\right)-i(S C)^{+}\right]^{2}} \text { dove } x=1,2, \ldots, n
$$

(ii) Non-ideal, using the formula:

$$
d_{A i}^{-}=\sqrt{\sum_{x=1}^{n}\left[i\left(S C x_{A i}\right)-i(S C)^{-}\right]^{2}} \text { dove } x=1,2, \ldots, n
$$

- estimate the proximity of each alternative to the ideal solution using the formula:

$$
v_{i}=\frac{d_{i}^{-}}{d_{i}^{+}+d_{i}^{-}}
$$

Having estimated the proximity of the initiative(s) which are to be assessed, and of the TS and SRS reference solutions to the ideal solution, the position of Piano di Zona Le Fontane, with respect to the TS and SRS reference solutions has been verified. The assessment results (Table 6) show that the SRS reference solution should be in the first position, followed by the SH initiative Piano di Zona Le Fontane and the TS reference solution is in third place.

Piano di Zona Le Fontane is, therefore, characterized by lower values when compared to the SRS reference solution and is superior to the TS reference solution. Subsequently, it is appropriate to assess which of the two solutions-SRS or TS-it falls closer to. Considering the median distance 
of the two SRS and TS reference solutions, the Piano di Zona Le Fontane SH initiative has a greater proximity to the SRS than to the TS reference solution. Therefore, it may be considered next to an ethical investment. The case study could be considered by socially-responsible funds operators for inclusion in the investment basket in relation to the threshold considered by the socially-responsible funds managers.

Table 6. Results of assessment.

\begin{tabular}{lccccc}
\hline \multicolumn{5}{c}{ Social Housing Piano di Zona Le Fontane } \\
\hline Distance from Ideal Solution & 29.6961 & Distance from Non-ideal Solution & 47.7065 & Vicinity & 0.6163 \\
\hline \multicolumn{5}{c}{ SRS (Socially Responsible Solution) } \\
\hline Distance from Ideal Solution & 14.2486 & Distance from Non-ideal Solution & 61.0019 & Vicinity & 0.8107 \\
\hline \multicolumn{5}{c}{ TS (Traditional Solution) } \\
\hline Distance da Ideal Solution & 66.1039 & Distance from Non-ideal Solution & 18.0519 & Vicinity & 0.2145 \\
\hline
\end{tabular}

In the case in which the initiative had been more close to the TS solution, it would have been considered as a traditional investment, but not a SRIF.

The initiative being assessed could have had a proximity to the ideal solution that is: (i) higher than both the SRS and the TS solutions; in this case, the initiative(s) may be considered a SRIF; or (ii) less, closer to both the SRS solution and the TS solution; in this case, the initiative(s) cannot be considered a SRIF, nor would it have the prerequisites for a traditional-type investment.

Therefore, the results obtained by applying the assessment procedure allowed us to sort between the alternatives (reference and real) verifying the reciprocal distances. Consequently the level of correspondence between the real initiative and the defined parameters characterizing a SRIF has been identified.

\section{Conclusions}

RE initiatives that pursue aims related to ethical finance can be included in the socially-responsible funds' investment basket $[49,50]$. By relying on "alternatives" to the investment channels by which RE renovation and development is traditionally financed (non-socially-responsible banks, investment funds, club deals, crowdfunding), businesses operating in RE can increase the possibility of initiating responsible and sustainable housing projects.

The procedure can be considered a tool that is quick and easy to implement, even in the absence of a decision aid specialist, thus, it can be used even within ordinary socially-responsible fund management competent structures.

The management structures of the socially-responsible funds have decision and deliberative powers and, consequently, responsibility for the success of investments to be undertaken. The lack of tools highlighting components of a SRIF results in the long-term for monetary resource allocation decisions, currently between 18 and 24 months from the preparatory phase to the approval stage of the financing proposal. The proposed evaluation procedure, particularly regarding SRIFs in RE, could be considered as a protocol in the capital allocation decision making process, making it more transparent and, thus, increasing responsibility in the management of socially-responsible funds. Indeed, the standardized use of the procedure can have a positive impact on reduction of time for resources allocation which is one of the key prerequisites for greater dynamism in the RE market segments of the SRIF.

Furthermore, the procedure can be applied to check whether certain initiatives in RE (SH) satisfy the requirements of SRIFs; in this way it can be used in the management of socially-responsible funds, allowing one to intervene when balancing business initiatives. 
From this application, the beneficial effects connected both to the related business generated by this sector and the effects of the physical regeneration/revitalization of the RE can be noticed.

The appraisal procedure allows to recognize when one or more RE initiatives can be considered as "ethical" helping to bring together the socially-responsible funds which are part of the available financial enterprises aimed at satisfying new financial, social, and environmental needs. These kinds of initiatives and, generally, land-transformation interventions, may also effectively contribute to the resolution of problems, such as urban decay, therefore increasing the quality of man-made spaces and, consequently, the living conditions of the population [51].

Author Contributions: The work must be attributed in equal parts to the authors.

Conflicts of Interest: The authors declare no conflict of interest.

\section{References}

1. Pivo, G.; Fisher, J. Income, value, and returns in socially responsible office properties. J. Real Estate Res. 2010, $32,243-270$.

2. Gangi, F. La Finanza Etica Durante le Crisi Finanziarie Nel Nuovo Millennio. modelli Teorici ed Evidenze Empiriche; Guida Editori: Naples, Italy, 2010.

3. Basso, A.; Funari, S. Relative Performance of SRI Equity Funds: An analysis of European Funds using Data Envelopment Analysis; University of Venice: Venice, Italy, 2010; Volume 201, pp. 1-27.

4. Eurosif. European SRI Study 2016. Available online: http://www.eurosif.org/wp-content/uploads/2016/ 11/SRI-study-2016-LR-.pdf (accessed on 31 March 2017).

5. Erhemjamts, O.; Li, Q.; Venkateswaran, A. Corporate social responsibility and its impact on firms' investment policy, organizational structure, and performance. J. Bus. Ethics 2013, 118, 395-412. [CrossRef]

6. Eurosif. Water Theme Report, 1st in a Series. 2008. Available online: http:/ /www.eurosif.org (accessed on 24 April 2017).

7. Eurosif. Biodiversity Theme Report, 2nd in a Series. 2009. Available online: http://www.eurosif.org (accessed on 24 April 2017).

8. Gri Realizing Rights; UN Global Compact. A Resource Guide to Corporate Human Rights Reporting. 2009. Available online: http:/ / www.globalreporting.org (accessed on 24 April 2017).

9. UK Social Investment Forum. Green and Ethical Investment-A Course for Financial Advisers. 2009. Available online: http:/ /www.uksif.org (accessed on 24 April 2017).

10. EFFAS. KPIs for ESG. A guideline for the Integration of ESG into Financial Analysis and Corporate Valuation. 2009. Available online: http:/ /www.effas.org (accessed on 24 April 2017).

11. The Organisation for Economic Co-operation and Development (OECD). OECD Principles of Corporate Governance. 2004. Available online: http:/ / www.oecd.org (accessed on 24 April 2017).

12. Eurosif. Remuneration Theme Report, 3rd in a Series. 2010. Available online: http://www.eurosif.org (accessed on 24 April 2017).

13. Cheng, B.; Ioannou, I.; Serafeim, G. Corporate social responsibility and access to finance. Strat. Manag. J. 2014, 35, 1-23. [CrossRef]

14. KPMG. European Responsible Investing Fund Survey 2015. Available online: https://home.kpmg. com/lu/en/home/insights/2015/03/european-responsible-investing-fund-survey-2015.html (accessed on 24 April 2017).

15. United Nations Environment Programme Finance Initiative (UNEP FI). The Principles for Positive Impact Finance-A Common Framework to Finance the Sustainable Development Goals. 2016. Available online: https://europa.eu/capacity4dev/unep/document/principles-positive-impact-financecommon-framework-finance-sustainable-development-goals (accessed on 24 April 2017).

16. Investor Network on Climate Risk (CERES-INCR); Institutional Investors Group on Climate Change (IIGCC); Investor Group on Climate Change (IGCC); Principles for Responsible Investment (PRI); Royal Institution of Chartered Surveyors (RICS); United Nations Environment Programme Finance Initiative (UNEP FI). Sustainable Real Estate Investment. Implementing the Paris Climate Agreement: An Action Framework. February 2016. Available online: https://www.unpri.org/explore/?q=sustainable+real+estate+ investment\&hd $=$ on\&hg $=$ on\&he $=0$ on\&ptv $=\& t v=($ accessed on 24 April 2017). 
17. Roberts, C.; Rowley, S.; Henneberry, J. The impact of landscape quality on property investment decisions. J. Prop. Invest. Financ. 2012, 30, 69-82. [CrossRef]

18. Bonde, M.; Song, H.S. Does greater energy performance have an impact on real estate revenues? J. Sustain. Real Estate 2013, 5, 174-185.

19. De Mare, G.; Granata, M.F.; Nesticò, A. Weak and Strong Compensation for the Prioritization of Public Investments: Multidimensional Analysis for Pools. Sustainability 2015, 7, 16022-16038. [CrossRef]

20. Newell, G. The Strategic Significance of Environmental Sustainability by Australian-listed Property Trusts. J. Prop. Invest. Financ. 2008, 26, 522-540. [CrossRef]

21. Cajias, M.; Fuerst, F.; McAllister, P.; Nanda, A. Do responsible real estate companies outperform their peers? Int. J. Strateg. Prop. Manag. 2014, 18, 11-27. [CrossRef]

22. Di Giuli, A.; Kostovetsky, L. Are red or blue companies more likely to go green? Politics and corporate social responsibility. J. Financ. Econ. 2014, 111, 158-180. [CrossRef]

23. Scanlon, K.; Whitehead, C.; Arrigoitia, M.F. (Eds.) Social Housing in Europe; John Wiley \& Sons: Hoboken, NJ, USA, 2014.

24. Hopkins, M. The Planetary Bargain: Corporate Social Responsibility Comes of Age; Springer: Berlin, Germany, 2016.

25. Falkenbach, H.; Lindholm, A.L.; Schleich, H. Review articles: Environmental sustainability: Drivers for the real estate investor. J. Real Estate Lit. 2010, 18, 201-223.

26. Dhaliwal, D.S.; Li, O.Z.; Tsang, A.; Yang, Y.G. Voluntary nonfinancial disclosure and the cost of equity capital: The initiation of corporate social responsibility reporting. Acc. Rev. 2011, 86, 59-100. [CrossRef]

27. Kerscher, A.N.; Schäfers, W. Corporate social responsibility and the market valuation of listed real estate investment companies. Zeitschrift für Immobilienökonomie 2015, 1, 117-143. [CrossRef]

28. Eichholtz, P.; Kok, N.; Quigley, J.M. Doing well by doing good? Green office buildings. Am. Econ. Rev. 2010, 100, 2492-2509. [CrossRef]

29. Sardinha, I.D.; Reijnders, L.; Antunes, P. Using corporate social responsibility benchmarking framework to identify and assess corporate social responsibility trends of real estate companies owning and developing shopping centres. J. Clean. Product. 2011, 19, 1486-1493. [CrossRef]

30. Warren-Myers, G. The value of sustainability in real estate: a review from a valuation perspective. J. Prop. Invest. Financ. 2012, 30, 115-144. [CrossRef]

31. Busch, T.; Bauer, R.; Orlitzky, M. Sustainable development and financial markets: Old paths and new avenues. Bus. Soc. 2016, 55, 303-329. [CrossRef]

32. Dixon, T.; Colantonio, A.; Shiers, D.E.; Reed, R.G.; Wilkinson, S.; Gallimore, P. A Green Profession: A Global Survey of RICS Members and Their Engagement with the Sustainability Agenda. J. Prop. Invest. Financ. 2008, 26, 460-481. [CrossRef]

33. The SROI Network. A Guide to Social Return on Investment. 2012. Available online: http://www. socialvalueuk.org/resources/sroi-guide/ (accessed on 24 April 2017).

34. Tajani, F.; Morano, P. Evaluation of vacant and redundant public properties and risk control: A model for the definition of the optimal mix of eligible functions. J. Prop. Invest. Financ. 2017, 35, 75-100. [CrossRef]

35. Demyanyk, Y.; Hasan, I. Financial crises and bank failures: A review of prediction methods. Omega 2010, 38, 315-324. [CrossRef]

36. Maliene, V. Specialised property valuation: Multiple criteria decision analysis. J. Retail Leisure Prop. 2011, 9 , 443-450. [CrossRef]

37. Arkesteijn, M.H.; Binnekamp, R. Real estate portfolio decision making. In Proceedings of the Third International Symposium on Engineering Systems-CESUN, Delft, The Netherlands, 18-20 June 2012.

38. Ferreira, F.A.; Spahr, R.W.; Sunderman, M.A. Using multiple criteria decision analysis (MCDA) to assist in estimating residential housing values. Int. J. Strateg. Prop. Manag. 2016, 20, 354-370. [CrossRef]

39. Ribeiro, M.I.; Ferreira, F.A.; Jalali, M.S.; Meidutè-Kavaliauskienè, I. A fuzzy knowledge-based framework for risk assessment of residential real estate investments. Technol. Econ. Dev. Econ. 2017, 23, 140-156. [CrossRef]

40. Directive 2014/95/EU of the European Parliament and of the Council of 22 October 2014 amending Directive 2013/34/EU as Regards Disclosure of Non-Financial and Diversity Information by Certain Large Undertakings and Groups. (Text with EEA Relevance). OJ L 330, 15.11.2014. pp. 1-9. Available online: http:/ / eur-lex.europa.eu/legal-content/EN/TXT/PDF/?uri=CELEX:32014L0095\&from=EN (accessed on 2 June 2017). 
41. Directive 2013/34/EU of the European Parliament and of the Council of 26 June 2013 on the Annual Financial Statements, Consolidated Financial Statements and Related Reports of Certain Types of Undertakings, Amending Directive 2006/43/EC of the European Parliament and of the Council and Repealing Council Directives 78/660/EEC and 83/349/EEC. (Text with EEA Relevance). OJ L 182, 29.6.2013. pp. 19-76. Available online: http:/ / eur-lex.europa.eu/legal-content/EN/TXT/PDF/?uri=CELEX:32013L0034\&from= EN (accessed on 2 June 2017).

42. Investimenti Socialmente Responsabili: La Mappa dei Fondi. Available online: http://www.lamiafinanzagreen.it/analisi/1496-per-cominciare/19763-investimenti-socialmente-responsabili-la-mappa-dei-fondi (accessed on 31 March 2017).

43. Associazione Aree Urbane Dismesse (AUDIS). La matrice della Qualità Urbana di AUDIS. 2013. Available online: http:/ / www.audis.it/index.html?pg=12\&sub=38\&id=14\&y=2013 (accessed on 31 March 2017).

44. Nesticò, A.; Macchiaroli, M.; Pipolo, O. Costs and Benefits in the Recovery of Historic Buildings: The Application of an Economic Model. Sustainability 2015, 7, 14661-14676. [CrossRef]

45. Ishizaka, A.; Nemery, P. Multi-Criteria Decision Analysis. Methods and Software; John Wiley \& Sons Ltd.: Chichester, UK, 2013; ISBN 978-1-119-97407-9.

46. Battisti, F.; Guarini, M.R. Public Interest Evaluation in Negotiated Public-Private Partnership. Int. J. Multi-Crit. Decis. Mak. 2017, 7, in press.

47. Guarini, M.R.; Battisti, F. Benchmarking Multi-criteria Evaluation: A Proposed Method for the Definition of Benchmarks in Negotiation Public-Private Partnerships. In Computational Science and Its Applications_ICCSA 2014; Murgante, B., Misara, S., Rocha, A.M.A.C., Torre, C.M., Rocha, J.G., Falcão, M.I., Taniar, D., Apduhan, B.O., Gervasi, O., Eds.; Lecture Notes in Computer Science; Springer: Cham, Germany, 2014; Volume 8581, pp. 208-223. [CrossRef]

48. Morano, P.; Locurcio, M.; Tajani, F.; Guarini, M.R. Urban Redevelopment: A Multi-criteria Valuation Model Optimized through the Fuzzy Logic. In Computational Science and Its Applications_ICCSA 2014; Murgante, B., Misara, S., Rocha, A.M.A.C., Torre, C.M., Rocha, J.G., Falcão, M.I., Taniar, D., Apduhan, B.O., Gervasi, O., Eds.; Lecture Notes in Computer Science; Springer: Cham, Germany, 2014; Volume 8581, pp. 161-175. [CrossRef]

49. Cortez, M.C.; Silva, F.; Areal, N. The performance of European socially responsible funds. J. Bus. Ethics 2009, 87, 573-588. [CrossRef]

50. Sandberg, J.; Juravle, C.; Hedesstrom, T.M.; Hamilton, I. The heterogeneity of socially responsible investment. J. Bus. Ethics 2009, 87, 519-533. [CrossRef]

51. Rugolo, A.; Calabrò, F.; Scrivo, R. The Assessment Tool for the Design of the Territories. The Impacts from the Road Infrastructure in the Inland Areas of the Province of Reggio Calabria. Procedia-Soc. Behav. Sci. 2016, 223, 534-541. [CrossRef]

(c) 2017 by the authors. Licensee MDPI, Basel, Switzerland. This article is an open access article distributed under the terms and conditions of the Creative Commons Attribution (CC BY) license (http://creativecommons.org/licenses/by/4.0/). 